\title{
Personal and Socio-Psychological Characteristics of Farmers in Association with Performance of Different Farming Systems Adopted by farmers in Chickaballapura District of Karnataka, India
}

\author{
N.V. Shwetha* and Y.N. Shivalingaih \\ Department of Agricultural Extension, University of Agricultural Sciences, Bangalore, \\ Karnataka, India \\ *Corresponding author
}

\begin{tabular}{|l|}
\hline Key w o r d s \\
Performance, \\
Farming systems, \\
Social status
\end{tabular}

\section{A B S T R A C T}

The study was conducted in Chickaballapura district of Karnataka, during the year 2015-16 to find out the association between personal and socio-psychological characteristics of farmers with performance of different farming systems adopted by farmers. In Chickaballapura district, two taluks i.e. Sidlaghatta and Chintamanitaluks were purposefully selected for the study, since these taluks are having more diversified farming compared to other taluks. From each taluk, five villages have been selected. From each village, 12 farmers are selected, which include three farmers under FS-1, three farmers under FS-2, three farmers under FS-3 and three farmers under FS-4. Thus, the total sample size from two taluks and 10 villages is 120 . It was found that, the association between personal and socio-psychological characteristics with performance of FS-1 farmer, the variables achievement motivation, risk bearing ability and mass media participation had positive and significant association with performance at five per cent level of significance. With FS-2 farmers, the extension participation had positive and significant association with performance at one per cent level of significance. It was found that with FS-3 farmers, risk bearing ability and decision making ability had positive and significant association with performance at one per cent level of significance. With FS-4 farmers, education, farming experience, land holding, cropping intensity, management orientation, risk bearing ability, irrigation intensity, decision making ability, mass media participation and extension participation had positive and significant association with performance at five per cent level of significance. Majority of Ragi farmers perceived uneven rainfall $(95.00 \%)$, non-availability of labour (86.66 \%), lack of knowledge $(80.00 \%)$, high cost of fertilizers $(75.00 \%)$ are the major constraints. A good number of dairy farmer's perceived shortage of green fodder and lack of pucca house (92.22\%), high investment $(82.22 \%)$ as their major constraints. A great majority of sericulture farmers expressed that lack of knowledge about spacing $(86.66 \%)$, lack of irrigation facility $(83.33 \%)$ as the major constraints. Horticulture farmers expressed that lack of water for irrigation (93.33\%), interrupted power supply and price fluctuation, high cost of hybrids $(90.00 \%)$, as the major constraints. 


\section{Introduction}

In order to sustain a positive growth rate in agriculture, a holistic approach is the need of the hour. Farming system is a mix of farm enterprises in which farm families allocate resources for efficient utilization of the existing enterprises for enhancing productivity and profitability of the farm.

These farm enterprises are crop, livestock, aquaculture, agro-forestry, agri-horticulture and sericulture. In diversified farming, though crop and other enterprises coexist, the thrust is mainly to minimize the risk, while in such situations a judicious mix of one or more enterprises along with cropping, there exist a complimentary effect through effective recycling of wastes and crop residues which encompasses additional source of income to farmer. Combination of enterprises is focused around a few selected interdependent, interrelated and interlinking production system based on crops, animals and related subsidiary professions.

Farming system approach is not only a reliable way of obtaining fairly high productivity with considerable scope for resource recycling, but also concept of ecological soundness leading to sustainable agriculture. With increasing energy crisis due to shrinking of nonrenewable fossil-fuel based sources, the fertilizer nutrient cost have increased steeply and gradual withdrawal of fertilizer subsidy. It is expected to have further hike in the cost of fertilizers. This would leave the farmers with no option but to fully explore the potential alternate sources of plant nutrients at least for the partial substitution of the fertilizer nutrients for individual crops and in the cropping systems. Hence, it was decided to know the association between personal and socio-psychological characteristics of farmers with performance of different farming systems adopted by farmers.

\section{Materials and Methods}

The study was conducted during 2016 in Chickaballapura district which comes under eastern dry zone (Zone- 5) of Karnataka. In Chickaballapura district, two taluks i.e. Sidlaghatta and Chintamani taluks were purposefully selected for the study, since these taluks are having more diversified farming compared to other taluks. Out of five taluks, Sidlaghatta and Chintamani are purposively selected for the study since these taluks have diversified farming systems compared to other taluks. From each taluk, five villages have been selected. From each village, 12 farmers are selected which include three farmers under FS-1, three farmers under FS-2, three farmers under FS-3 and three farmers under FS-4. Thus, the total sample size from two taluks and 10 villages is 120 . In the present investigation, Ex-post facto research design was used. Data was collected by using a detailed interviewed schedule employed personal interview method. The responses were scored, quantified, categorised and tabulated using statistical methods like percentage, mean, standard deviation, frequencies and chi square test.

\section{Key farming systems selected for the study}

Crop production (FS-1)

Crop production and dairy (FS-2)

Crop production, dairy and sericulture (FS-3)

Crop production, dairy, sericulture and horticulture (FS-4)

\section{Results and Discussion}

Results from the Table 1 shows the overall profile of the farmers adopting different farming systems viz., more than half of the respondents $(58.33$ per cent) belonged to 
middle age group, 36.66 per cent of the respondents had high school education, more than three-fifth of the respondents $(62.50 \%)$ belonged to high farming experience category, nearly three-fifth $(58.3 \%)$ of the respondents are marginal farmers, majority $(61.67 \%)$ of the respondents comes under medium level of cropping intensity, nearly two-fifth of the respondents $(37.50 \%)$ were found in high scientific orientation category, about 66.33 per cent of the farmers belonged to medium cropping pattern category, that nearly half of the respondents $(49.16 \%)$ of the farmers were belonged to medium Management orientation category, more than one third of the respondents $(34.16 \%)$ had high level of achievement motivation, medium innovative proneness was exhibited by a great majority $(82.50 \%)$ of farmers, about 57.50 per cent of the farmers were having medium level of deferred gratification, about three-fourth $(75.83 \%)$ of the farmers were belonged to medium level of risk bearing ability category, medium irrigation intensity was exhibited by 66.67 per cent of farmers, two-fifth of the respondents belonged to medium category (40.00\%), more than half of the farmers $(53.33 \%)$ belonged to medium extension contact category, more than three-fifth of the farmers $(61.66 \%)$ were under medium decision making ability category, about 45.00 per cent of the farmers belonged to medium mass media participation category.

The possible reason for this pattern of profile of farmers adopting different farming systems may be due to most of them is middle aged and they are enthusiastic and have more efficiency than young farmers or old farmers.

Due to fragmentation of land holding most of them are marginal farmers. All the farmers are relatively educated and they having good experience in farming, hence they have medium mass media participation and medium risk bearing ability.
Table 2 revealed that association between personal and socio-psychological characteristics with performance of FS-1, FS2, FS-3 and FS-4 farmer. Under FS-4 the variables achievement motivation, risk bearing ability and mass media participation had positive and significant association with performance at five per cent level of significance. Under FS-2 farmers, the extension participation had positive and significant association with performance at one per cent level of significance, whereas farming experience, land holding, scientific orientation, management orientation, mass media participation and decision making ability had positive and significant association with performance at five per cent level of significance.

It was found that under FS-3 farmers, risk bearing ability and decision making ability had positive and significant association with performance at one per cent level of significance, whereas education, farming experience, land holding, cropping intensity, cropping pattern, management orientation, irrigation intensity, mass media participation and extension participation had positive and significant association with performance at five per cent level of significance.

Under FS-4 farmers, education, farming experience, land holding, cropping intensity, management orientation, risk bearing ability, irrigation intensity, decision making ability, mass media participation and extension participation had positive and significant association with performance at five per cent level of significance, whereas education, farming experience, land holding, cropping intensity, management orientation, risk bearing ability, irrigation intensity, decision making ability, mass media participation and extension participation had positive and significant association with performance at five per cent level of significance. 
Table.1 Overall profile of the farmers adopting different farming systems

\begin{tabular}{|c|c|c|c|c|c|}
\hline SI. No. & Characteristics & Category & Number & $\%$ & \\
\hline \multirow[t]{3}{*}{1} & \multirow{3}{*}{ Age } & Young (<32years) & 27 & 22.30 & \\
\hline & & Middle (32-56 years) & 70 & 58.33 & \\
\hline & & Old ( $>56$ years $)$ & 23 & 19.60 & \\
\hline \multirow[t]{5}{*}{2} & \multirow[t]{5}{*}{ Education } & Illiterate & 21 & 17.50 & \multirow{5}{*}{$\begin{array}{c}\text { Mean }=2.7 \\
\text { S.D }=1.2\end{array}$} \\
\hline & & Primary school & 26 & 21.66 & \\
\hline & & High school & 44 & 36.66 & \\
\hline & & Pre-University & 16 & 13.33 & \\
\hline & & Graduation and above & 13 & 10.83 & \\
\hline \multirow[t]{3}{*}{3} & \multirow{3}{*}{ Farming experience } & Low & 12 & 10.0 & \\
\hline & & Medium & 33 & 27.5 & \\
\hline & & High & 75 & 62.5 & \\
\hline \multirow[t]{3}{*}{4} & \multirow{3}{*}{$\begin{array}{l}\text { Land-holdings } \\
\text { (farm size) }\end{array}$} & Marginal farmers $(<2.5 .0$ acres $)$ & 70 & 58.3 & \multirow{3}{*}{$\begin{array}{c}\text { Mean }=2.3 \\
\text { S.D }=1.6\end{array}$} \\
\hline & & Small farmers (20.5-5.0 acres) & 40 & 33.3 & \\
\hline & & Big farmers( $>5.0$ acres $)$ & 10 & 8.3 & \\
\hline \multirow[t]{3}{*}{5} & \multirow[t]{3}{*}{ Cropping intensity } & Low & 18 & 15.00 & \multirow{3}{*}{$\begin{array}{c}\text { Mean }=22.3 \\
\text { S.D }=3.9\end{array}$} \\
\hline & & Medium & 74 & 61.67 & \\
\hline & & High & 28 & 23.33 & \\
\hline \multirow[t]{3}{*}{$\overline{6}$} & \multirow{3}{*}{$\begin{array}{l}\text { Scientific } \\
\text { orientation }\end{array}$} & Low & 31 & 25.83 & \multirow{3}{*}{$\begin{array}{c}\text { Mean }=13.3 \\
\text { S.D }=2.0\end{array}$} \\
\hline & & Medium & 44 & 36.66 & \\
\hline & & High & 45 & 37.50 & \\
\hline \multirow[t]{3}{*}{7} & \multirow[t]{3}{*}{ Cropping pattern } & Low & 12 & 10.00 & \multirow{3}{*}{$\begin{array}{c}\text { Mean }=2.3 \\
\text { S.D }=1.1\end{array}$} \\
\hline & & Medium & 81 & 66.33 & \\
\hline & & High & 27 & 23.67 & \\
\hline \multirow[t]{3}{*}{8} & \multirow{3}{*}{$\begin{array}{l}\text { Management } \\
\text { orientation }\end{array}$} & Low & 23 & 19.16 & \multirow{3}{*}{$\begin{array}{c}\text { Mean }=18.1 \\
\text { S. } D=1.2\end{array}$} \\
\hline & & Medium & 59 & 49.16 & \\
\hline & & High & 38 & 31.66 & \\
\hline \multirow[t]{3}{*}{9} & \multirow{3}{*}{$\begin{array}{l}\text { Achievement } \\
\text { motivation }\end{array}$} & Low & 40 & 33.33 & \multirow{3}{*}{$\begin{array}{c}\text { Mean }=14.8 \\
\text { S.D }=1.0\end{array}$} \\
\hline & & Medium & 39 & 32.50 & \\
\hline & & High & 41 & 34.16 & \\
\hline
\end{tabular}

Conti....

\begin{tabular}{|c|c|c|c|c|c|}
\hline SI. No. & Characteristics & Category & Number & $\%$ & \\
\hline \multirow[t]{2}{*}{10} & \multirow[t]{2}{*}{ Innovative proneness } & Low & 15 & 12.50 & \multirow{2}{*}{$\begin{array}{c}\text { Mean }=15.8 \\
\text { S.D }=0.69\end{array}$} \\
\hline & & Medium & 99 & 82.50 & \\
\hline \multirow[t]{3}{*}{11} & \multirow[t]{3}{*}{ Deferred gratification } & Low & 27 & 22.50 & \multirow{3}{*}{$\begin{array}{c}\text { Mean }=24.6 \\
\text { S. } D=2.8\end{array}$} \\
\hline & & Medium & 69 & 57.50 & \\
\hline & & High & 24 & 20.00 & \\
\hline \multirow{2}{*}{12} & \multirow{2}{*}{ Risk bearing ability } & Medium & 91 & 75.83 & \multirow{2}{*}{$\begin{array}{l}\text { Mean=4.9 } \\
\text { S.D }=0.12\end{array}$} \\
\hline & & High & 16 & 13.33 & \\
\hline \multirow[t]{3}{*}{13} & \multirow[t]{3}{*}{ Irrigation intensity } & Low & 19 & 15.83 & \multirow{3}{*}{$\begin{array}{c}\text { Mean=4.9 } \\
\text { S.D }=2.3\end{array}$} \\
\hline & & Medium & 80 & 66.67 & \\
\hline & & High & 21 & 17.50 & \\
\hline \multirow[t]{3}{*}{15} & \multirow[t]{3}{*}{ Extension contact } & Low & 30 & 25.00 & \multirow{3}{*}{$\begin{array}{c}\text { Mean=3.5 } \\
\text { S.D }=1.6\end{array}$} \\
\hline & & Medium & 64 & 53.33 & \\
\hline & & High & 26 & 21.66 & \\
\hline \multirow[t]{3}{*}{16} & \multirow{3}{*}{$\begin{array}{l}\text { Decision making } \\
\text { ability }\end{array}$} & Low & 27 & 22.50 & \multirow{3}{*}{$\begin{array}{c}\text { Mean }=11.5 \\
\text { S.D }=1.7\end{array}$} \\
\hline & & Medium & 74 & 61.66 & \\
\hline & & High & 19 & 15.83 & \\
\hline \multirow[t]{3}{*}{17} & \multirow{3}{*}{$\begin{array}{l}\text { Mass media } \\
\text { participation }\end{array}$} & Low & 47 & 39.16 & \multirow{3}{*}{$\begin{array}{c}\text { Mean }=5.9 \\
\text { S.D }=1.3\end{array}$} \\
\hline & & Medium & 54 & 45.00 & \\
\hline & & High & 19 & 15.83 & \\
\hline
\end{tabular}


Table.2 Association between personal and socio-psychological characteristics with performance of different farming systems adopted by farmers

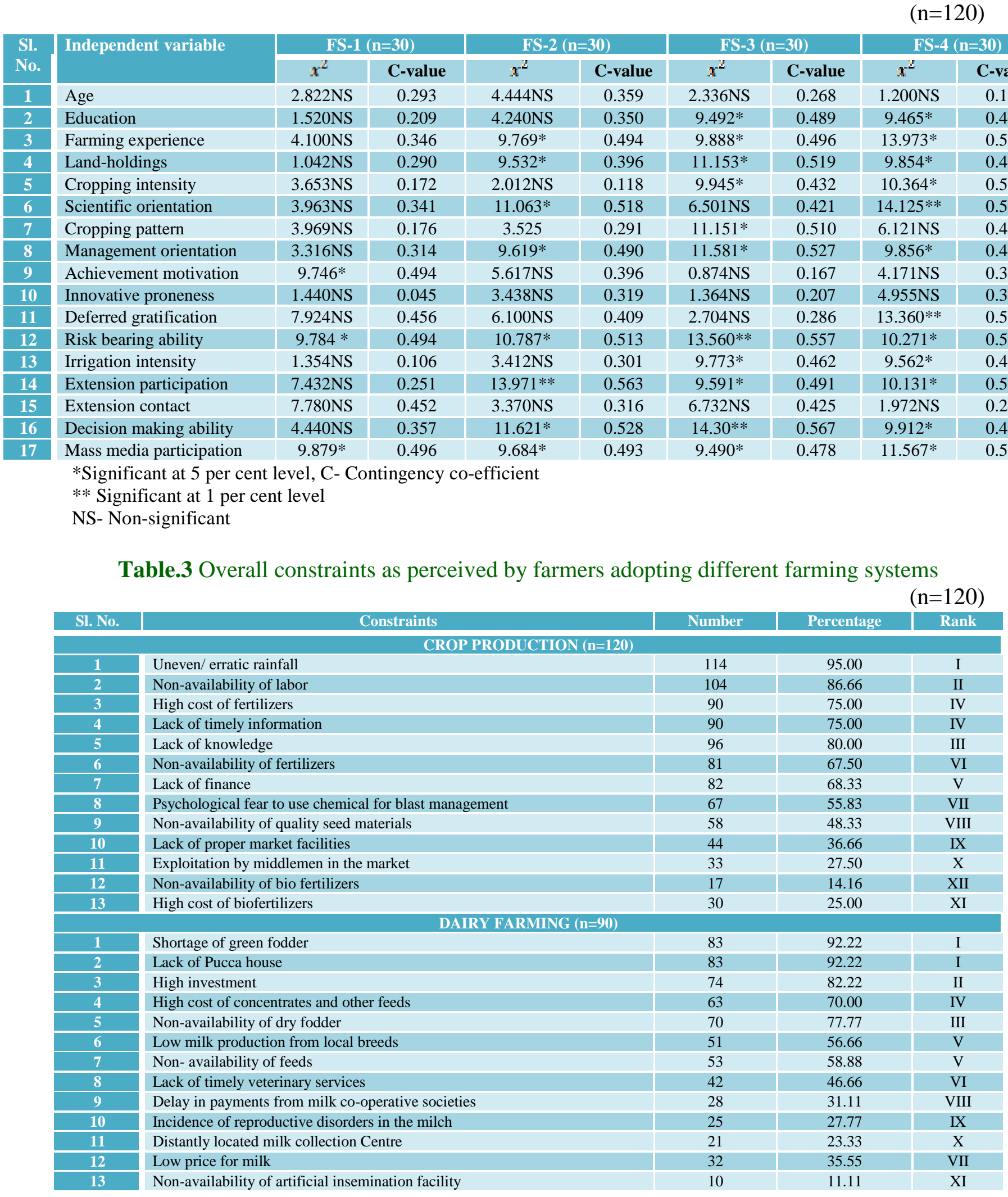


Contd...

\begin{tabular}{|r|l|c|c|c|}
\hline & SERICULTURE $(\mathbf{n = 6 0})$ & & \\
\hline $\mathbf{1}$ & Lack of Irrigation facility & 50 & 83.33 & II \\
\hline $\mathbf{2}$ & Lack of knowledge about spacing & 52 & 86.66 & I \\
\hline $\mathbf{3}$ & High cost of fertilizers & 41 & 68.33 & III \\
\hline $\mathbf{4}$ & Incidence of ujifly and white muscardine & 41 & 68.33 & III \\
\hline $\mathbf{5}$ & Improper disinfection of rearing house & 41 & 68.33 & III \\
\hline $\mathbf{6}$ & Non-availability of labor & 29 & 48.33 & III \\
\hline $\mathbf{7}$ & Untimely intercultural operations & 30 & 50.00 & IV \\
\hline $\mathbf{8}$ & Non-availability of loans from bank & 30 & 50.00 & IV \\
\hline $\mathbf{9}$ & Fluctuations in market prices & 24 & 40.00 & V \\
\hline $\mathbf{1 0}$ & High investment & 22 & 36.66 & VI \\
\hline $\mathbf{1 1}$ & Lack of timely technical advise & 8 & 13.33 & VIII \\
\hline $\mathbf{1 2}$ & Lack of knowledge and skill about proper maintenance of rearing bed & 10 & 16.66 & VII \\
\hline $\mathbf{1 3}$ & Lack of knowledge about intercropping & 7 & 11.66 & IX \\
\hline $\mathbf{1 4}$ & Non-availability of DFLs in time & & & \\
\hline & & 28 & 93.33 & I \\
\hline $\mathbf{1}$ & Lack of water for irrigation & 27 & 90.00 & II \\
\hline $\mathbf{2}$ & Price fluctuation & 24 & 80.00 & III \\
\hline $\mathbf{3}$ & High cost of hybrids & 23 & 76.66 & IV \\
\hline $\mathbf{4}$ & High cost of fertilizers and chemicals & 21 & 70.00 & V \\
\hline $\mathbf{5}$ & Non-availability of fertilizers & 20 & 66.66 & VI \\
\hline $\mathbf{6}$ & Non availability of labour in time & 19 & 63.33 & VII \\
\hline $\mathbf{7}$ & Non availability of recommended chemicals for seed treatment & 17 & 56.66 & VIII \\
\hline $\mathbf{8}$ & Non-availability of weedicides and bio agents & 16 & 53.33 & IX \\
\hline $\mathbf{9}$ & Lack of knowledge on important production technologies & 14 & 46.66 & X \\
\hline $\mathbf{1 0}$ & Lack of timely technical advice & 7 & 23.33 & XI \\
\hline $\mathbf{1 1}$ & Lack of transportation facility & 6 & 20.00 & XII \\
\hline $\mathbf{1 2}$ & Interference of middlemen & & \\
\hline
\end{tabular}

The possible reason is that, the education level of an individual is directly related to performance of the individual, it helps the individual to make progress in right direction developing awareness about new technology leading to adoption of technologies in different enterprises and the mass media carry more information on improved methods of cultivation. People are ready to change and more innovative would certainly adopt more number of improved agricultural practices. Higher Cosmo-politeness behaviour leads to higher information seeking on agriculture and growing of different crops and practicing different farming systems in same piece of land avoids the farmers from failure of crops and ensures the crop sustainability. These findings are in confirmation with those findings of Jyothi (2005).
The overall constraints faced by farmers in adopting different farming systems are presented in the Table 3. A great majority of farmers perceived uneven rainfall $(95.00 \%)$, non-availability of labor (86.66\%), lack of knowledge $(80.00 \%)$, high cost of fertilizers $(75.00 \%)$ and lack of timely information $(75.00 \%)$ as their major problems followed by lack of finance $(68.33 \%)$ and nonavailability of fertilizers $(67.50 \%)$. A good number of dairy farmer's perceived shortage of green fodder and lack of pucca house (92.22\%), high investment $(82.22 \%)$ and high cost of concentrate feeds and other feeds $(70.00 \%)$ as their major constraints. Other constraints expressed are non-availability of dry fodder $(77.77 \%)$, low milk production from local breeds (56.66 \%), non-availability of feeds $(58.88 \%)$ and lack of timely 
veterinary services (46.66 \%). A great majority of sericulture farmers expressed that, lack of knowledge about spacing (86.66 \%), lack of irrigation facility $(83.33 \%)$ as the major constraints followed by high cost of fertilizers, incidence of uzifly and white muscardine, improper disinfection of rearing house, non-availability of labour $(68.33 \%)$, non-availability of loans from bank $(50.00 \%)$ as other important constraints expressed in sericulture farming (Table 3). Most of the horticulture farmers expressed that lack of water for irrigation (93.33\%), interrupted power supply and price fluctuation, high cost of hybrids $(90.00 \%)$, high cost of fertilizers and chemicals $(80.00 \%)$, non-availability of fertilizers $(76.66 \%)$ as the major constraints followed by non-availability of recommended chemicals for seed treatment $(70.00 \%)$, nonavailability of labor in time $(66.66 \%)$, nonavailability of weedicides and bio-agents (63.33\%), lack of knowledge on production technology $(56.66 \%)$ and untimely technical advice (46.66 \%) as their other major constraints.

To overcome the above problems extension specialists need to educate the farmers to adopt moisture conserving technologies in dry land farming, promote drip irrigation and mulching techniques in horticulture production and provide the fertilizer chemicals at subsidized cost. Provide labour saving technologies, proper guidance about high yielding varieties in case of tomato, provide timely information about plant protection measures and conduct training programmes about improved cultivation practices in tomato.
As the above constraints listed in crop production, dairy and sericulture are crucial and demand driven activities, extension professionals should take at most care and make necessary arrangements for timely supply of critical inputs and quality seed materials, conduct skill oriented demonstrations, training on latest technologies and provide timely technical advice, on a constant basis to enhance the productivity.

\section{References}

Agarwal, S. B., Singh, C. B. and Jha, S. K., 2007. Constraints in adoption of cross breeding technology in different regions of India. Indian. J. Dairy Sci., 60(5): 360-363.

Chaudhari, R. R., 2006. A study on entrepreneurial behavior of dairy farmers. M.Sc. (Agri.) Thesis (Unpub.) Univ. Agric. Sci., Dharwad.

Pottappa, K., 2008. Knowledge and adoption of potato growers in Chikkaballapur district- A study, M.Sc. (Agri.) Thesis (Unpub.), Univ. Agri. Sci., Bangalore.

Sunil Kumar, G.M., 2004. A study on farmers' knowledge and adoption of production and post-harvest technology in tomato crop of Belgaum district in Karnataka. M.Sc. (Agri.) Thesis (Unpub.), Univ. Agric. Sci., Dharwad.

Yashahwini, M.A., 2013. Effectiveness of Front Line Demonstrations of Krishi Vigyana Kendra on FLD farmers of Mandya district, M.Sc. (Agri) Thesis (Unpub.), Univ. Agric. Sci., Bangalore. P: 1-128.

\section{How to cite this article:}

Shwetha, N.V. and Shivalingaih, Y.N. 2018. Personal and Socio-Psychological Characteristics of Farmers in Association with Performance of Different Farming Systems Adopted by farmers in Chickaballapura District of Karnataka, India. Int.J.Curr.Microbiol.App.Sci. 7(03): 787-793. doi: https://doi.org/10.20546/ijcmas.2018.703.092 